\title{
Two new varieties of Alysicarpus (Fabaceae) from Peninsular India
}

\author{
Dalavi J.V. ${ }^{1}$, Bramhadande S.P. ${ }^{2}$, Mane R.N. ${ }^{1}$, Mane P.R. ${ }^{3}$ \& S.R. Yadav ${ }^{1 *}$ \\ ${ }^{1}$ Angiosperm Taxonomy Laboratory, Department of Botany, Shivaji University, Kolhapur, Maharashtra - 416 004, India \\ ${ }^{2}$ Naoroji Godrej Center for Plant Research, Shirwal, Satara, Maharashtra - 412 801, India \\ ${ }^{3}$ Department of Botany, Y.C. Science College, Karad, Satara, Maharashtra - 415 124, India \\ *E-mail: sryadavdu@rediffmail.com
}

\begin{abstract}
Alysicarpus tetragonolobus Edgew. var. falcatus and $A$. tetragonolobus. var. micranthus are described here as two new varieties of Alysicarpus tetragonolobus from Maharashtra. Both varieties are morphologically close to A. tetragonolobus var. tetragonolobus but differ in their morphology and all grow sympatrically. Observations in the field as well as in cultivation for four years showed that all the varieties retain their diagnostic characters and no intermediates were observed.
\end{abstract}

Keywords: Alysicarpus, Desmodieae, Fabaceae, Maharashtra.

\section{Introduction}

Alysicarpus Desv. belonging to tribe Desmodieae (Fabaceae) comprises 35 species and 20 infraspecific taxa worldwide. India is the centre of diversification for the genus and is represented by 18 species and 9 varieties of which 8 species and 4 varieties are endemic (Pokle, 2017; Dalavi et al., 2019).

During field explorations in Kolhapur district, the authors came across two interesting specimens of Alysicarpus which were further studied in natural and cultivated conditions for four years. Perusal of the literature (Sanjappa, 1992; Gholami \& Pandey, 2016; Pokle, 2017; Dalavi et al., 2019) and comparison with specimens housed at BLAT, BSI, CAL, E, MH, K (Thiers, continuously updated), it is concluded that they belong to undescribed infra-

Received: 10.12.2020; Revised \& Accepted: 15.01.2021

Published Online: 31.03 .2021 specific taxa of A. tetragonolobus Edgew. Hence, both are described here as new varieties and are further discussed below with detailed descriptions and figures.

\section{Material and Methods}

Materials were collected in the months of September to December from 2016-2020 at Kolhapur (Maharashtra). All specimens collected were processed using standard herbarium techniques (Jain \& Rao, 1977). The authors have collected and recorded the necessary data regarding habitat, habit, morphological variations, phenology and geographic information such as coordinates of the type localities during the field visits. The comprehensive photography of the morphological characters was taken by using D6000 camera (Nikon, Japan) and some microphotographs were taken under CMZ-6 stereomicroscope (Labomed, Japan). The specimens collected from the type localities are deposited in the Herbarium of Department of Botany, Shivaji University, Kolhapur, Maharashtra (SUK!), India, for detailed study. The scientific novelty of the specimens was confirmed by a critical survey of the literature (Sanjappa, 1992; Gholami \& Pandey, 2016; Pokle, 2017; Dalavi et al., 2019) and comparing with specimens available at BLAT, BSI, CAL, E, MH, K (Thiers, continuously updated) and images of specimens available in the virtual database of JSTOR (2020), Edinburgh herbarium (https://data.rbge.org.uk/search/ herbarium/) and Kew Herbarium (http:// apps.kew.org/herbcat/navigator.do). 


\section{Taxonomic treatment}

Alysicarpus tetragonolobus Edgew. var. falcatus Dalavi, Bramhad., P.R.Mane \& S.R.Yadav, var. nov.

Fig. 1

Morphologically allied to A. tetragonolobus Edgew. var. tetragonolobus but distinct by its habit (procumbent and slender $v s$. procumbent to erect and robust), corolla (mono-coloured vs. mono to bi-coloured), pod (falcate vs. straight), articles (compressed, bi-convex, isobilateral $v s$. tetragonolobus or quadrangular), terminal article (continued into a stout beak $v$ s. minute and articulated beak) and beak (persistent $v s$. caducous).

Type: INDIA, Maharashtra, Kolhapur district, N 16.678644, E 74.263666, Rajaram lake, 05.11.2019, S.P. Bramhadande, J.V. Dalavi, P.R. Mane \& S.R. Yadav JVD-1392 (holo CAL!; iso CAL!, SUK! \& BSI!).

Annual, branched procumbent herbs, to $10-20 \mathrm{~cm}$ tall. Stems slender, sparingly branched, sparsely pilose. Leaves unifoliolate, elliptic-ovate to lanceolate, $1.5-3.5 \times 0.3-0.5 \mathrm{~cm}$., base rounded and apex acute to rounded, margins entire, dorsiventrally glabrous to sparsely pilose on both the surfaces; petioles $0.3-0.5 \mathrm{~cm}$ long. Racemes terminal, $4-10 \mathrm{~cm}$ long. Flowers $0.7-1 \mathrm{~cm}$ across; pedicels $c .5 \mathrm{~mm}$ long, usually paired; bracts ovate to broad lanceolate, c. $3 \times 1.5 \mathrm{~mm}$, acuminate, ciliate, faintly veined; bracteoles linear, c. $2 \times 0.3 \mathrm{~mm}$, ciliate along margins. Calyx c. $6 \mathrm{~mm}$ across; sepals 5 , anterior two united forming $\mathrm{V}$-shaped notch in the middle, scarious. Petals 5, papilionaceous; standard petal broadly ovate, 4-6 $\times 4-5 \mathrm{~mm}$, emarginate at apex, clawed at base, glabrous, dark pink; wing petals $0.5-0.6 \times 0.2-0.4 \mathrm{~cm}$, clawed, glabrous, pink to red; keel petals ovate-elliptic, c. $4 \times 1 \mathrm{~mm}$, clawed, pink. Stamens diadelphous (9+1); staminal column c. $3 \mathrm{~mm}$ long; filaments glabrous. Gynoecium c. 3 mm long; style bent at middle, sparsely hairy on the apical portion. Pods sickle shaped or falcate, 1$1.5 \mathrm{~cm}$ long, dorsiventrally compressed, articles $2-$ 6 , terminal article continued into thick stout beak; beak c. $3 \mathrm{~mm}$, non-articulated, persistent; article $c$. $3 \times 2.5 \mathrm{~mm}$, more or less biconvex, isobilateral, slightly longer than broader, deeply reticulated, green when young, black to brown when mature. Seeds ovate to spherical, c. $2 \times 1.5 \mathrm{~mm}$, slightly compressed, yellowish brown, polished.

Flowering \& fruiting: Flowering from September to November and fruiting from October to January.

Habitat: Common along lakesides in wet grasslands in association with Alysicarpus. tetragonolobus var. tetragonolobus, A. vaginalis (L.) DC., Desmodium triflorum (L.) DC., Zornia gibbosa Span. (all Fabaceae), Eleocharis atropurpurea (Retz.) J.Presl \& C.Presl. (Cyperaceae), and Pulicaria wightiana Clarke (Asteraceae).

Etymology: The variety epithet 'falcatus' comes from the falcate shape of the pods.

Distribution: Rajaram Lake (Kolhapur), Maharashtra, India.

Conservation status: No detailed data is available on the distribution of this variety, hence assessed here as Data Deficient (DD) as per the guidelines of IUCN (2019).

Notes: The variety has a very distinct pod in the whole genus, as the majority of species have pods showing a distinct articulation at the base of the beak, but here, the terminal article is directly converted into beak.

Alysicarpus tetragonolobus Edgew. var. micranthus Dalavi, Mane, \& S.R.Yadav var. nov.

Fig. 2

Closely allied to A. tetragonolobus Edgew. var. tetragonolobus but differs by its racemes (congested $v$ s. elongated), flowers (4-6 mm across $v s .>8 \mathrm{~mm}$ across), corolla (included in the calyx $v$ s. exserted from calyx), standard petal (longer than broad $v$ s. broader than long), claw (nearly equal to limb $v$ s. much smaller than limb) and articles of pods (longer than broad $v s$. as long as or broader than long).

Type: INDIA, Maharashtra, Kolhapur district, Ujalaiwadi, N 16.662947, E 74.27649112, 12.11.2020, J.V. Dalavi, R.N. Mane \& S.R. Yadav JVD-1393 (holo CAL!; iso CAL!, SUK! \& BSI!).

Annual, sub-erect, sparingly branched herbs, to 15$30 \mathrm{~cm}$ high. Stems sparingly branched, terete, with 


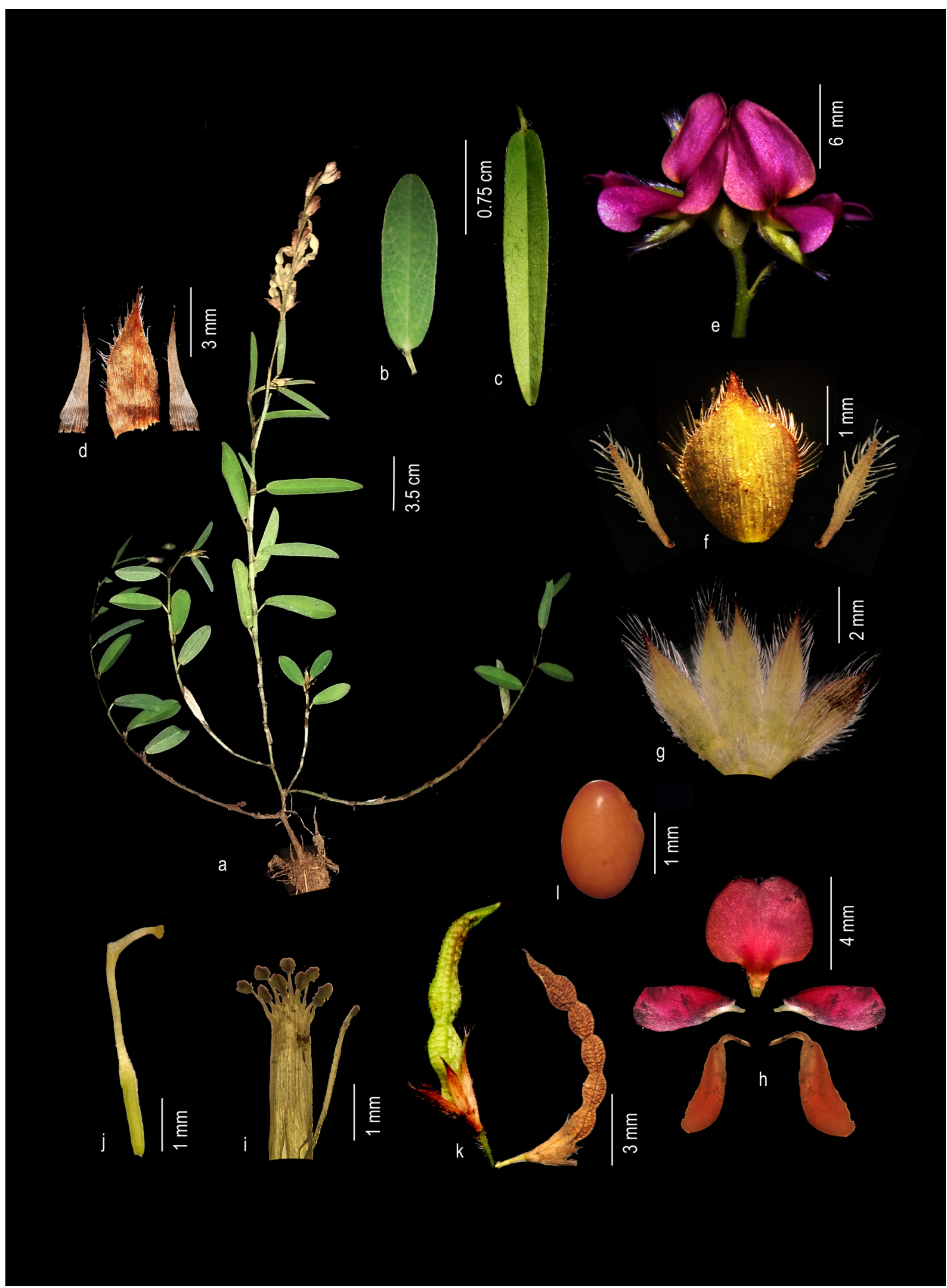

Fig. 1. Alysicarpus tetragonolobus var. falcatus Dalavi, Bramhad., P.R. Mane \& S.R.Yadav: a. Habit; b. \& c. Leaves; d. Stipule and stipels; e. Flowers; f. Bract and bracteoles; g. Calyx; h. Dissected corolla; i. Androecium; j. Gynoecium; k. Pods; I. Seed (from JVD-1392; photos by J.V. Dalavi). 


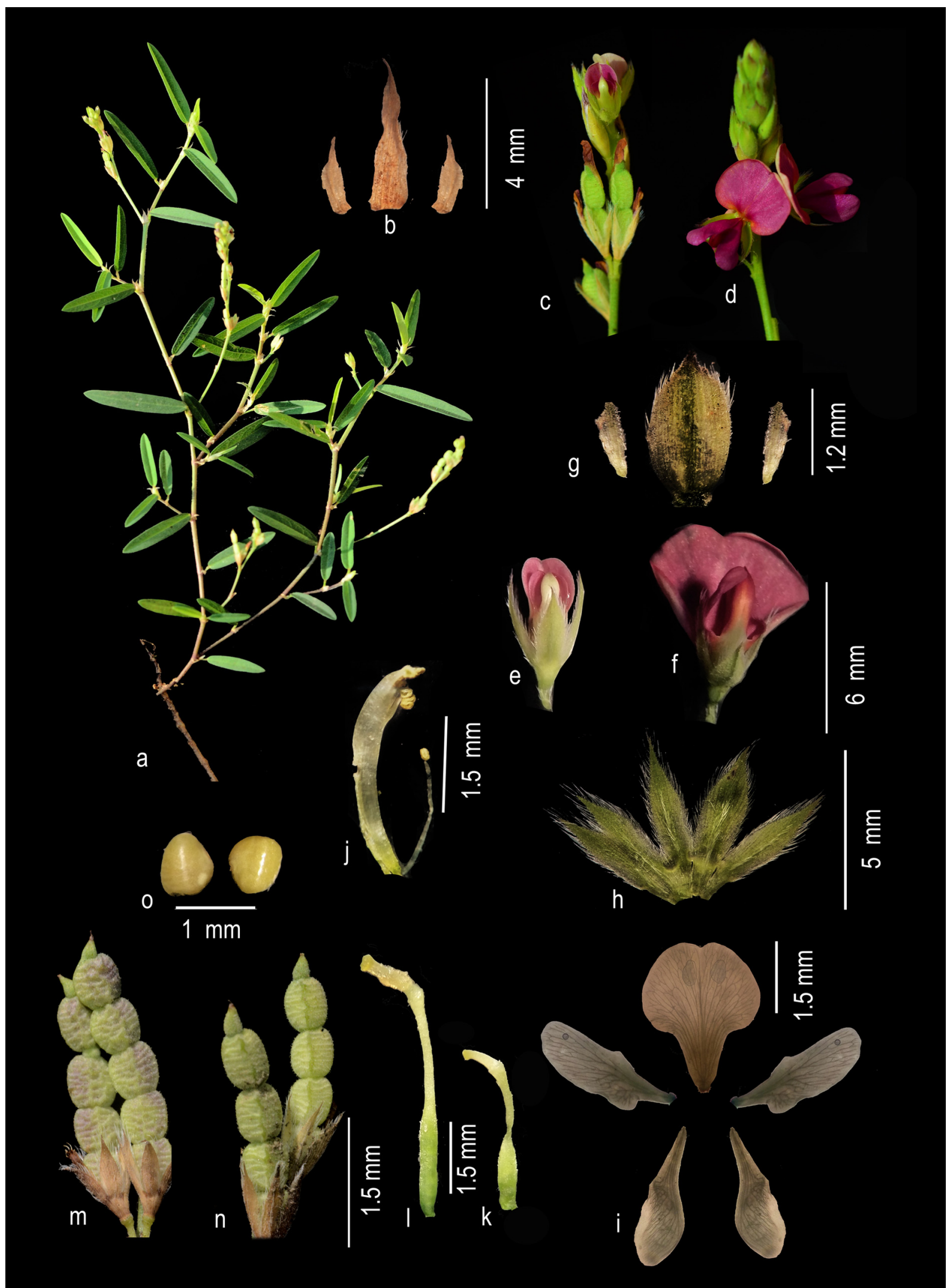

Fig. 2. Images of Alysicarpus tetragonolobus var. micranthus Dalavi, Mane \& S.R.Yadav (a-c, e, g-k, m, n, o) and Alysicarpus tetragonolobus Edgew. (d, f, l, m): a. Habit; b. Stipule and stipels; c \& d. Inflorescence; e \& f. Flower; g. Bract and bracteoles; h. Calyx; i. dissected corolla; j. Androecium; k \& I. Gynoecium; m \& n. Pods; 0. Seeds (from JVD-1393; photos by J.V. Dalavi). 
woody root stock, $c .0 .3 \mathrm{~cm}$ in diam., minutely hairy to glabrous, with distinct nodes due to remnants of scarious stipules and stipels, internodes as long as or longer than leaves. Leaves unifoliolate, ovate, oblong to elliptic, $1-2.5 \times 0.25-0.5 \mathrm{~cm}$, thick, rounded at base, sub-acute at apex, glabrous to pilose at both the surfaces, green above pale beneath; stipules scarious, c. $4 \times 1 \mathrm{~mm}$, striated, acute at apex, ciliate and deltoid along margin; stipels lanceolate, c. $2 \mathrm{~mm}$ long, striated, ciliated and minutely deltoid at margins; petioles c. $0.25 \mathrm{~cm}$ long, sparsely ciliate. Inflorescence congetsed, unbranched racemes, 2$4.5 \mathrm{~cm}$ long. Flowers $0.4-0.6 \mathrm{~cm}$ across; pedicel 1.5-2 mm, straight, sparse ciliate; bracts broad ovate, c. $2.5 \times 1.5 \mathrm{~mm}$, acute to acuminate at apex, striate, ciliate throughout; bracteoles linear-lanceolate, 1$1.2 \times$ c. $0.5 \mathrm{~mm}$, striate, ciliate, green. Calyx $4-5 \times$ $6.5-7 \mathrm{~mm}$ when fully dissected; sepals 5 , scarious, connate at base, anterior two sepals united forming a deep notch in the middle; posterior one and lateral two ovate, acute to acuminate at apex; ciliate outside, striate. Corolla $4-6 \mathrm{~mm}$ across, as long as or shorter than calyx, mono-coloured, pink; standard petals narrow-ovate, c. $3 \times 2 \mathrm{~mm}$, longer than broad, claw as long as limb, triangular, limb shallowly notched at apex, pink; wing petals narrow ovate to elliptic, $c .3 \times 1.5 \mathrm{~mm}$, clawed; keel petals boat shaped c. $2.5 \times 0.5 \mathrm{~mm}$, pink. Stamens diadelphous (9+1); staminal column c. $2.5-3 \mathrm{~mm}$ long; filaments glabrous. Gynoecium c. 3 mm long; ovary elongated, sub-terete, style curved, stigma capitate. Pods, 1-2.5 cm long, beaded, tetragonolobus, articles longer than broader, deeply reticulated, straw coloured. Seeds ovate, spherical to ovate-elongate, 1-1.5 × $1 \mathrm{~mm}$, slightly compressed.

Flowering \& fruiting: Flowering from September to November and fruiting from October to January.

Habitat: Common in open grasslands in association with Aeschynomene aspera L., Alysicarpus bupleurifolius (L.) DC., A. naikianus Pokle, $A$. tetragonolobus, $A$. vaginalis (L.) DC., Mimosa pudica L. (all Fabaceae), Alternanthera tenella Colla (Amaranthaceae), Dichanthium annulatum (Forssk.)
Stapf. and Eragrostis unioloides (Retz.) Nees (both Poaceae).

Etymology: The variety epithet 'micranthus' refers to the character of the flowers, which in the variety are very small and included in the calyx (micro= small, anthus= flower).

Distribution: Endemic to India.

Conservation status: This variety is only reported from its type locality and is uncommon in open grasslands. Since data on population and distribution is not available, it is provisionally assessed here as Data Deficient (DD) (IUCN, 2019).

Notes: It was observed that all flowers produced pods and it is suspected that the variety is adapted to self-pollination breeding, which, however, needs further detailed investigations.

\section{Key to the varieties of Alysicarpus tetragonolobus}

1. Pods falcate or sickle-shaped, beak nonarticulated var. falcatus

1. Pods straight, beak articulated ....................... 2

2. Corolla included in calyx........ var. micranthus

2. Corolla exserted from calyx ........................... 3

3. Leaves ovate-oblong, few upper leaves linear; inflorescence many flowered; pod articles turgid var. tetragonolobus

3. Leaves linear, few lower leaves ovate; inflorescence few flowered; pod articles flattened var. pashanensis

\section{Acknowledgements}

The authors are thankful to the Head, Department of Botany, Shivaji University Kolhapur, for laboratory facilities and also thankful to Prof. D.V. Pokle for confirmation of the novelties. SRY is thankful to the Indian National Science Academy for financial assistance. PRM is thankful to SARTHI for financial assistance and SPB is thankful to the Naoroji Godrej Center for Plant Research for laboratory facilities and encouragement. 


\section{Literature Cited}

DALAVI J.V., BRAMHADANDE S., POKLE D. \& S. YADAV 2019. Alysicarpus bhuibavadensis (Fabaceae), a new species from Western Ghats of India. Phytotaxa 427(4): 285-290. https://doi.org/10.11646/phytotaxa.427.4.7

GHOLAMI A. \& A.K. PANDEY 2016. Alysicarpus poklianus (Fabaceae, Desmodieae), a new species from India. PhytoKeys 68: 117-124. https://doi.org/10.3897/ phytokeys.68.9975

IUCN 2019. IUCN Red List Categories and Criteria: Version 14. IUCN, Species Survival Commission, Gland and Cambridge. (Prepared by the Standards and Petitions Committee.) Available at: http://www.iucnredlist.org/ documents/RedListGuidelines. pdf
JAIN S.K. \& R.R. RAO 1977. A handbook of field and herbarium methods. Today \& Tomorrow's Printers and Publishers, New Delhi.

JSTOR 2020. Global Plants Database. (Accessed on 01.10.2020).

POKLE D.S. 2017. Genus Alysicarpus in India. MGM College of Agriculture Biotechnology, Aurangabad.

SANJAPPA M. 1992. Legumes of India. Bishen Singh Mahendra Pal Singh, Dehra Dun.

THIERS B.M. continuously updated. Index Herbariorum: a global directory of public herbaria and associated staff, New York Botanical Garden's Virtual Herbarium. Available at: http://sweetgum.Nybg.org/ih/(Accessed on 20.03.2021). 